\title{
WebML + for Communication of Information Flows: An Empirical Study
}

\author{
David Lowe and Rachatrin Tongrungrojana
}

University of Technology, Sydney

PO Box 123 Broadway NSW 2007, Australia

\{david.lowe, rachatrin.tongrungrojana\}@uts.edu.au

\section{Introduction}

A key element in supporting the development of Web systems is suitable Web modelling languages. Most existing work on Web modelling (such as WebML 1]) has focussed on understanding the structure of the information space and how this relates to the underlying content. These approaches however have rarely addressed the connection between detailed design aspects and the broader information environment, particularly in terms of the flow of information between the system, the organisation, and external entities. Work on information architectures $[2$ address these issues to a limited extent, especially when incorporating an understanding of user interactions and engagement with a site 3 . However these models are rarely consistent with those used for lower level information modeling. Our work to date has focused on the development of a notation (based on extending WebML to incorporate abstract information flows and referred to as WebML+) that addresses these limitations and bridges the gap between business models and information design [4]5. This characteristic is crucial in Webdevelopment where the systems under development often lead to fundamental changes in business operations. In this paper we present the results of an empirical evaluation of whether or not WebML+ provides more rapid and consistent communication of information flows within Web system design processes.

\section{WebML+}

WebML+ enables developers to express the core information features of a system at an abstract level without committing to detailed designs. It can be considered as an extension to WebML (see [1] and www.webml.org). The purpose of WebML+ modeling is to define the internal and the external information flows within a Web system. As with WebML, we have defined both a graphical notation and an XML-based formal notation for representing WebML+ models (though we do not show the formal XML DTD here).

Figure 1 shows an example WebML+ model: FreeMail is a provider of Webbased e-mail that allows users to send and receive messages through a Web interface. The system (shown as a dashed geometrical polygon) encloses a set of information units which represent coherent and cohesive domains of information that are managed by, or necessary for utilising, the system. We also have both 


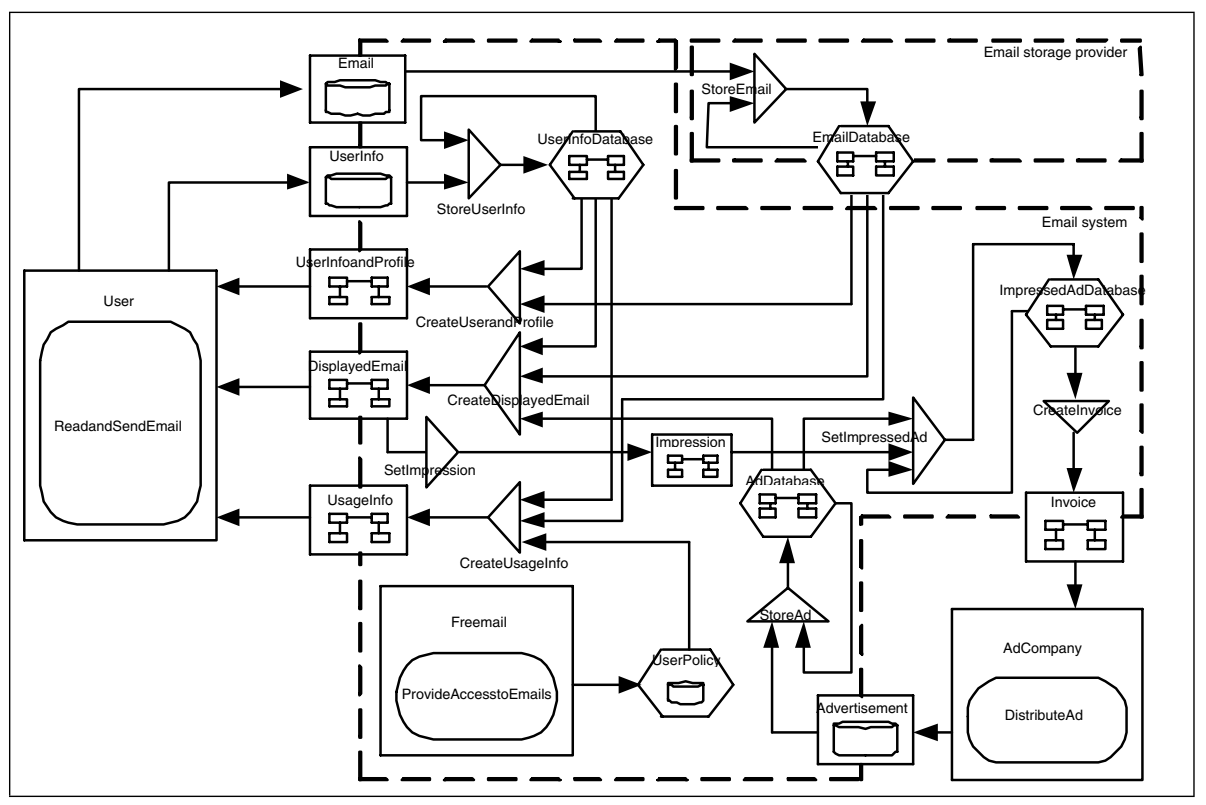

Fig. 1. Typical Web System represented using WebML+

external actors (e.g. users) and internal actors (e.g. the FreeMail organisation) who supply and consume information units. Some information units are provided directly by actors (e.g. the advertisements) whilst others are derived from other units. These derivations (shown as triangles with incoming and outgoing arrows) capture the inter-relationships between the information units.

\section{$3 \quad$ Experimental Design}

Our intention was to investigate whether the WebML+ modelling technique could (when contrasted with purely textual descriptions) provide more rapid and consistent communication of information flows. An experiment was carried out where we investigated the ability of two groups of participants (one having access to textual descriptions, and the other to WebML+ models) to answer questions about information flows within the Web system. In order to minimise the likelihood of the results being biased by the specific construction of the two descriptions (WebML+ and textual), they were authored by different people. Each of the two authors was able to provide half the questions to be asked of the participants, and then to design their descriptions in light of the full set of questions. Further, we developed two different Web system scenarios (a Webbased Email service and an online-auction system) and provided the textual and WebML + models of both. The participants were randomly allocated to one of the scenarios, and one of the descriptions. The participants were then asked to answer a series of questions about the system described. The answers 
Table 1. The averaged number of correct answers for each group of participants

\begin{tabular}{lcc}
\hline & MEAN & MEDIAN \\
Of textual description group & 6.4 & 6 \\
Of WebML+ Group & 7.4 & 7.5 \\
\hline
\end{tabular}

were timed and recorded automatically. Steps were taken to address possible confounding factors such as the experience of the modeller and reader, and the type of scenario. This was counteracted by the adoption of multiple scenarios and through the way in which the descriptions and questions were constructed.

\section{Results and Discussion}

Table 1 shows the descriptive statistics for the two groups. We note that participants who read the WebML+ model had, on average, a greater number of correct answers than those who had read the textual description. Further, we took the Independent Samples T-Test to determine whether this difference was statistically significant. Whilst space prohibits inclusion of the details, we carried out an independent samples T-Test of the null hypothesis that the difference was not statistically significant. The results indicates that the null hypothesis can be rejected (i.e. the difference between the means of the two groups was statistically significant) at an $80 \%$ confidence level, but not at a $95 \%$ confidence level. Further data (beyond the 20 participants in the experiment) would be required to provide stronger power within the test.

Figure 2 shows the relationship between time spent on questions and the number of correct answers - i.e. how quickly participants could develop an understanding of the system. Figure $2 \mathrm{~h}$ shows our expectations prior to commencing the experiment. We had expected that the WebML+ participants would be able to more rapidly answer questions initially due to the graphical notation inherent in WebML+ and also expected that the participants who had the textual description would eventually be able to answer questions more correctly given that the text was not constrained by the limitations of a graphical notation.

Figure 2 $\mathrm{b}$ shows the actual experiment results. We find that both curves have similar characteristics. The deviation from our expected results may be caused by two possible factors. Firstly, the WebML+ participants did not have a significant prior degree of exposure to WebML+ concepts, leading to the need for greater time to understand the WebML+ models. To investigate this we conducted a sub-test with a small number of researchers who were more familiar with WebML+. Whilst not statistically rigourous, this subsequent result was much closer to that which we expected (i.e. Figure $2 \mathrm{k}$ ). Secondly, there was an unexpected confounding factor related to the participants use of the "search" facility in the browser find information when reading the textual descriptions - leading to an ability to answer the specific questions more rapidly without having to develop a broader understanding of the system. 


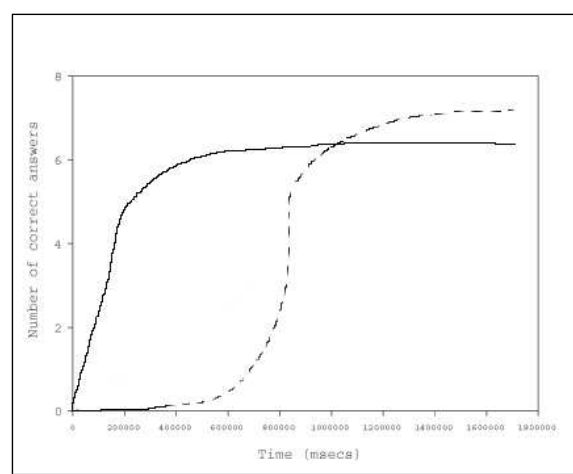

(a)

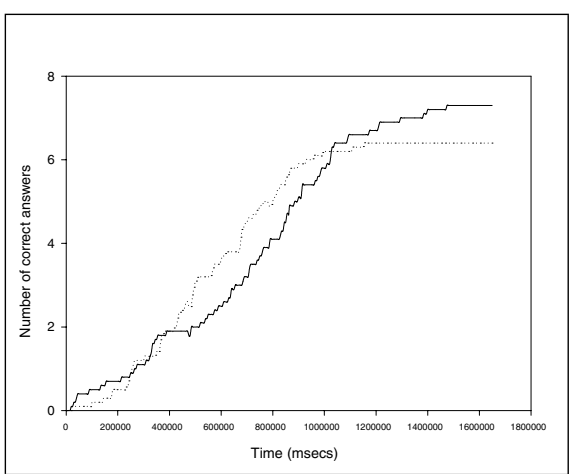

(b)

Fig. 2. Relationship between times spent on question and number of correct answers ( solid line $=$ WebML + , dotted line $=$ textual description $)$

\section{Conclusion and Future Work}

In this paper, we have presented an empirical evaluation of WebML+, a highlevel specification language for defining Web system information flows. The results provided an initial indication that WebML+ was indeed a useful tool. In brief, we found that participants could answer questions about information flows more correctly when they read the WebML + model as compared to participants who read a textual description of the system. This led to our conclusion that users are able to understand a system based on a WebML+ model more consistently than when based on a textual description.

\section{References}

1. Ceri, S., Fraternali, P., Bongio, A.: Web modeling language (WebML): a modeling language for designing web sites. In: Procs of WWW9 Conf, Amsterdam (2000)

2. Rosenfeld, L., Morville, P.: Information Architecture for the World Wide Web. O'Reilly (1998)

3. Haverty, M.: Information architecture without internal theory: An inductive design process. Journal of the American Society for Information Science \& Technology $\mathbf{5 3}$ (2002) 839

4. Tongrungrojana, R., Lowe, D.: WebML+: A web modeling language for modelling architectural-level information flows. Int $\mathrm{J}$ of Web Engineering and Technologies (2003-pending)

5. Lowe, D., Tongrungrojana, R.: WebML+ in a nutshell: Modelling architectural-level information flows. In: WWW2003: 12th International World Wide Web Conference, Budapest, Hungary (2003) 